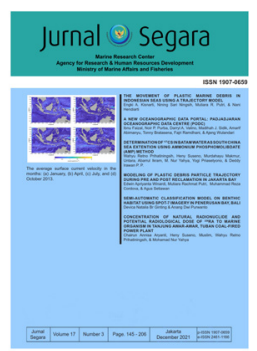

JURNAL SEGARA

http://ejournal-balitbang.kkp.go.id/index.php/segara

ISSN : 1907-0659

e-ISSN : 2461-1166

Nomor Akreditasi: 158/E/KPT/2021

\title{
THE MOVEMENT OF PLASTIC MARINE DEBRIS IN INDONESIAN SEAS USING A TRAJECTORY MODEL
}

\author{
Engki A. Kisnarti ${ }^{1,2)}$, Nining Sari Ningsih ${ }^{3)}$, Mutiara R. Putri ${ }^{3)}$, \& Nani Hendiarti ${ }^{4)}$ \\ ${ }^{1)}$ Doctoral Program in Earth Sciences, Faculty of Earth Sciences and Technology, Institute Technology of Bandung \\ 2)Universitas Hang Tuah \\ ${ }^{3}$ Research Group of Oceanography, Institute Technology of Bandung, Indonesia. \\ ${ }^{4}$ Deputy for Coordination of Environment and Forestry Management, \\ Coordinating Ministry for Maritime and Investment Affairs, Indonesia.
}

Received: 23 August 2021; Revised: 05 November 2021; Accepted: 12 Desember 2021

\begin{abstract}
There are many studies on ocean currents transporting plastic marine debris using hydrodynamic models and trajectories that have been carried out. However, it is still constrained to be applied in Indonesian waters. Therefore, this research aims to obtain the movement patterns of plastic marine debris, influenced by the dynamics of currents in Indonesian waters using hydrodynamic and trajectory models. The methodology used in this research is to use the Hamburg Shelf Ocean Model (HAMSOM) numerical model and the trajectory model. Plastic marine debris is assumed to be conservative particles at sea level with a macro size $\left(2.5 \mathrm{~cm}^{-1} \mathrm{~m}\right)$. The particles are released in 6 coastal cities (Manado, Balikpapan, Makassar, DKI Jakarta, Semarang, and Denpasar) at the month and stop at the end month (January, April, July, October). The results showed that particles originating from 6 coastal cities moved along the current to the surrounding areas only, across islands within the Indonesian territory, and even left Indonesian territory.
\end{abstract}

Keywords: Plastic marine debris, current, the trajectory model.

Corresponding author:

Jl. Pasir Putih I Ancol Timur, Jakarta Utara 14430. Email: engki.andri@hangtuah.ac.id 


\section{INTRODUCTION}

Marine debris is defined as waste from materials that have been created or used by humans and are intentionally disposed of or accidentally carried from land to sea or coast through rivers, sewage systems, and wind. This definition of marine debris does not include semi-solid remains (e.g., minerals and vegetables, kinds of paraffin, and chemicals that sometimes enter the ocean and beaches) (Coe \& Rogers, 1997; Galgani, 2010). Sources of marine debris can be classified into marine debris originating from beach tourists, fishers, the mainland, industry (NOAA, 2015). Types of waste can be distinguished by size, namely: mega (>1 m), macro $\left(2.5 \mathrm{~cm}^{-1} \mathrm{~m}\right)$, meso $(0.5-2.5 \mathrm{~cm})$, micro $(0.33-5.0 \mathrm{~mm})$, nano $(<1 \mathrm{~m})$ (Lippiatt et al., 2013).

One of the most significant contributors to marine debris in the marine environment is plastic. Its number is increasing due to its persistence and impact on the oceans, wildlife, and humans (Thompson et al., 2009). The amount of plastic marine debris that enters the sea can be influenced by several factors, namely the number of outputs carried by rivers, population density, and maritime activities. In addition, when plastic marine debris reaches the sea, the current has an influential role in spreading plastic marine debris.

Research on the role of ocean currents in Indonesian waters related to plastic marine debris has not developed much and is still limited. The author considers it very important to conduct research related to the plastic marine debris footprint by using a simulation model of ocean currents in Indonesian waters. Therefore, this study aims to examine the distribution of plastic marine debris in Indonesian waters. In this study, the authors no longer study the local distribution of plastic marine debris but more regionally (covering all Indonesian waters).

\section{METHODOLOGY}

\section{Hydrodynamic Model Design}

The research method involves the numerical modeling of HAMburg Shelf Ocean Model (HAMSOM) hydrodynamics, developed by Backhaus $(1983,1985)$ This is a three-dimensional (3D) baroclinic hydrodynamic model verified in Indonesian waters (Putri, 2005; Putri et al., 2017; Anwar et al., 2017; Anwar et al., 2018). Furthermore, the simulation has previously been performed for a year (2013) under normal conditions (not influenced by El-Nino Southern Oscillation/ENSO) (Huang et al., 2017).

The bathymetry data input was processed directly from the world map obtained from the Shuttle Radar Topography Mission (Jarvis et al., 2008). Each horizontal size $d x$, dy of 6 minutes $\left(1 / 10^{\circ}\right)$, dz by 20 vertical layers, and dt by 180 seconds. Furthermore, tidal data are used to generate force at the model area's open boundary. It was obtained from the Oregon State University Tidal Prediction Software (OPTS) global model (Egbert \& Svetlana, 2002), with a horizontal resolution of $1^{\circ} \times 1^{\circ}$. The atmospheric parameters used as input include average sea level pressure, air temperature, specific humidity, total cloud cover, wind, and precipitation levels, obtained from the National Center for Environment Prediction (NCEP). Monthly temperature and salinity data with quarter degrees (represent the world as $1440 \times 720$ quarterdegree longitude/latitude boxes) are obtained from the World Ocean Atlas (WOA) (Locarnini et al., 2013; Zweng et al., 2013). Furthermore, the atmospheric parameter, temperature, and salinity data were captured into the domain model to be used. One of the outputs of this hydrodynamic model is ocean currents, and then this current data will be used as input in the trajectory model. In the trajectory model, plastic waste is assumed to be conservative particles that do not undergo degradation, biodegradation, or mineralization. Therefore, this model only simulates the trajectory of particles in the surface layer.

\section{Trajectory Modeling}

The Lagrange method is used in the particle trajectory model, an approach method used to review fluid motion as the motion of a fluid parcel in a flow (Bowman et al., 2013). In this study, the particle trajectory model was adapted from the model used by Mayer (1995) by only observing the advection force on the horizontal surface to track the traces of floating plastic marine debris in Indonesian waters. The tracking of plastic marine debris will be carried out with a forward trajectory. The velocity field equation used in this model in the trajectory simulation (Equation 1).

$$
\underline{v}=\left\{\begin{array}{c}
u+u^{\prime} \\
v+v^{\prime} \\
w+w^{\prime}+w_{s}
\end{array}\right.
$$

The displacement of the particle from $\mathrm{x} 1$ to $\mathrm{x} 2$ can be calculated using the equation $d x=u(x) d t$, where $u(x)$ is the velocity at the western boundary of the box $\left(u_{b}\right)$ where the particle is located plus the particle distance from the western boundary of the box $(x)$ multiplied by $\partial u / \partial x$.

$$
u(x)=u_{b}+x \frac{\partial u}{\partial x}
$$

The equation $d x=u(x) d t$ is integrated to obtain the displacement of the particle from $\mathrm{x} 1$ to $\mathrm{x} 2$. 


$$
\int_{x_{1}}^{x_{2}} \frac{d x}{u(x)}=\int_{t}^{t+\Delta t} d t
$$

The integral result of the above equation is shown by Equation 4.

$$
x_{2}=\frac{\left(u_{b}+x_{1} \frac{\partial u}{\partial x}\right)^{\frac{\partial u}{\partial x^{\Delta t}}}-u_{b}}{\frac{\partial u}{\partial x}}
$$

\section{Data of Waste}

Waste data is used as input in running the path model. Waste data was obtained from the World Bank Group, the Coordinating Ministry for Maritime Affairs, and the Embassy of Denmark (2017), namely waste data from major cities in coastal areas of Indonesia, such as Manado, Makassar, Balikpapan, DKI Jakarta, Semarang, and Denpasar. These cities were selected as inputs for plastic marine debris to represent Indonesia's coastal areas through flow and monsoon currents. The data used is only $80 \%$ of the total plastic waste on land (Jambeck et al., 2015; Windom, 1992 in Krelling et al., 2017). Therefore, plastic marine debris, which is assumed to be particulate matter, will be distributed in the six big cities. The particle assumption is that one particle is equivalent to $1 \mathrm{~kg} \mathrm{~m}^{-3}$ (Table 1).

The simulation of the particle trajectory model in Indonesian waters is carried out using the trajectory model. Particles are released from each source grid at the beginning of each month until the end of the month: January (west season), April (transition season 1), July (east season), and October (transition season 2). The movement of particles per month in each city will be given a different color to determine the distribution pattern of plastic marine debris that leaves or remains in Indonesian waters.

\section{RESULTS AND DISCUSSION}

Overall, the average current direction in January moves from west to east (west monsoon) with a moderate current velocity on the surface of around 0.1-0.6 $\mathrm{m} \mathrm{s}^{-1}$. For local waters, such as waters near Balikpapan and Makassar (Makassar Strait), the current direction is northward; in the Lombok Strait, the average current moves north towards the Flores Sea, while around Manado, the current direction is southeast towards the Maluku Sea and the Seram Sea. In April and October, the average current velocity weakened compared to January, only reaching $0.1 \mathrm{~ms}^{-1}$. In general, the direction of the current began to reverse. In contrast to January, the average current in July moves from east to west (east monsoon). The current velocity also strengthened again to $0.6 \mathrm{~ms}^{-1}$. Although the input used in this current model is slightly different from the three-dimensional flow model using the finite volume numerical method (Mustika et al, 2015), the results of the flow simulation in October have shown similarities. Meanwhile, the overall simulation results for the waters near Balikpapan, the Makassar Strait, and the Lombok Strait, the current direction is southward (Figure 1). The results of this current simulation are not much different from the results of Wyrtki (1987); Gordon et al. (2003); Gordon et al. (2010); Mayer et al. (2010); Sprintall \& Revelard (2014).

The simulation results for January are shown in Figure 2. The figure shows that currents carry particles released near Manado waters only around the northeast of Manado. This phenomenon also occurs with particles released in Makassar waters. This happens because the current around the two waters moves to the northeast. Unlike the particles released in the waters of Balikpapan, some of these particles are carried by currents to the north (Bontang and Berau) and east (Makassar Strait).

Particles were also released in waters near DKI Jakarta, Semarang, and Denpasar. After a simulation for one month (January), it turned out that all particles from DKI Jakarta and Semarang were carried by the Java Sea current to the east, to the north of East Java. Slightly different from DKI Jakarta and Semarang particles, the particles released in Denpasar are carried

\begin{tabular}{|c|c|c|c|c|c|c|}
\hline No & $\begin{array}{l}\text { Location } \\
\text { City }\end{array}$ & Latitude & Longitude & $\begin{array}{l}\text { Plastic Mar } \\
\text { Total PMD } \\
\left(\mathrm{kg} \mathrm{m}^{-3}\right)\end{array}$ & $\begin{array}{l}\text { Debris (PMD) } \\
80 \% \times \text { PMD } \\
\left(\mathrm{kg} \mathrm{m}^{-3}\right)\end{array}$ & Particle assumption \\
\hline 1 & Manado & $1.6^{\circ} \mathrm{LU}$ & $124.7^{\circ} \mathrm{BT}$ & 23.47 & 19 & 19 \\
\hline 2 & Balikpapan & $1.5^{\circ} \mathrm{LS}$ & $116.8^{\circ} \mathrm{BT}$ & 62.23 & 50 & 50 \\
\hline 3 & Makassar & $5.0^{\circ} \mathrm{LS}$ & $119.3^{\circ} \mathrm{BT}$ & 87.52 & 70 & 70 \\
\hline 4 & DKI Jakarta & $5.8^{\circ} \mathrm{LS}$ & $106.8^{\circ} \mathrm{BT}$ & 97.72 & 78 & 78 \\
\hline 5 & Semarang & $6.7^{\circ} \mathrm{LS}$ & $110.4^{\circ} \mathrm{BT}$ & 52.60 & 42 & 40 \\
\hline 6 & Denpasar & $8.7^{\circ} \mathrm{LS}$ & $115.4^{\circ} \mathrm{BT}$ & 5.32 & 41 & 41 \\
\hline
\end{tabular}

Table 1. Location, amount of litter, and particle assumptions in the trajectory simulation 
by currents to the north. The particles are distributed in a small part in the Lombok Strait and mostly turn east after leaving the Lombok Strait towards the Flores Sea (north of East Nusa Tenggara).

The simulation results in April showed that the particles in the waters of Manado were carried to the Southwest and stranded in the waters around the north of North Sulawesi and Gorontalo. Likewise, with the particles released in Balikpapan, all particles from
Balikpapan are distributed entirely only to the middle part of the Makassar Strait (Northeast of Balikpapan), following the currents that occur around these waters. In contrast to January, most of the particles released around Makassar waters began to leave the source and were carried by currents towards the Southwest (towards the Java Sea) (Figure 3).

In April, the particles released in the waters near DKI Jakarta were carried by currents to the west and then
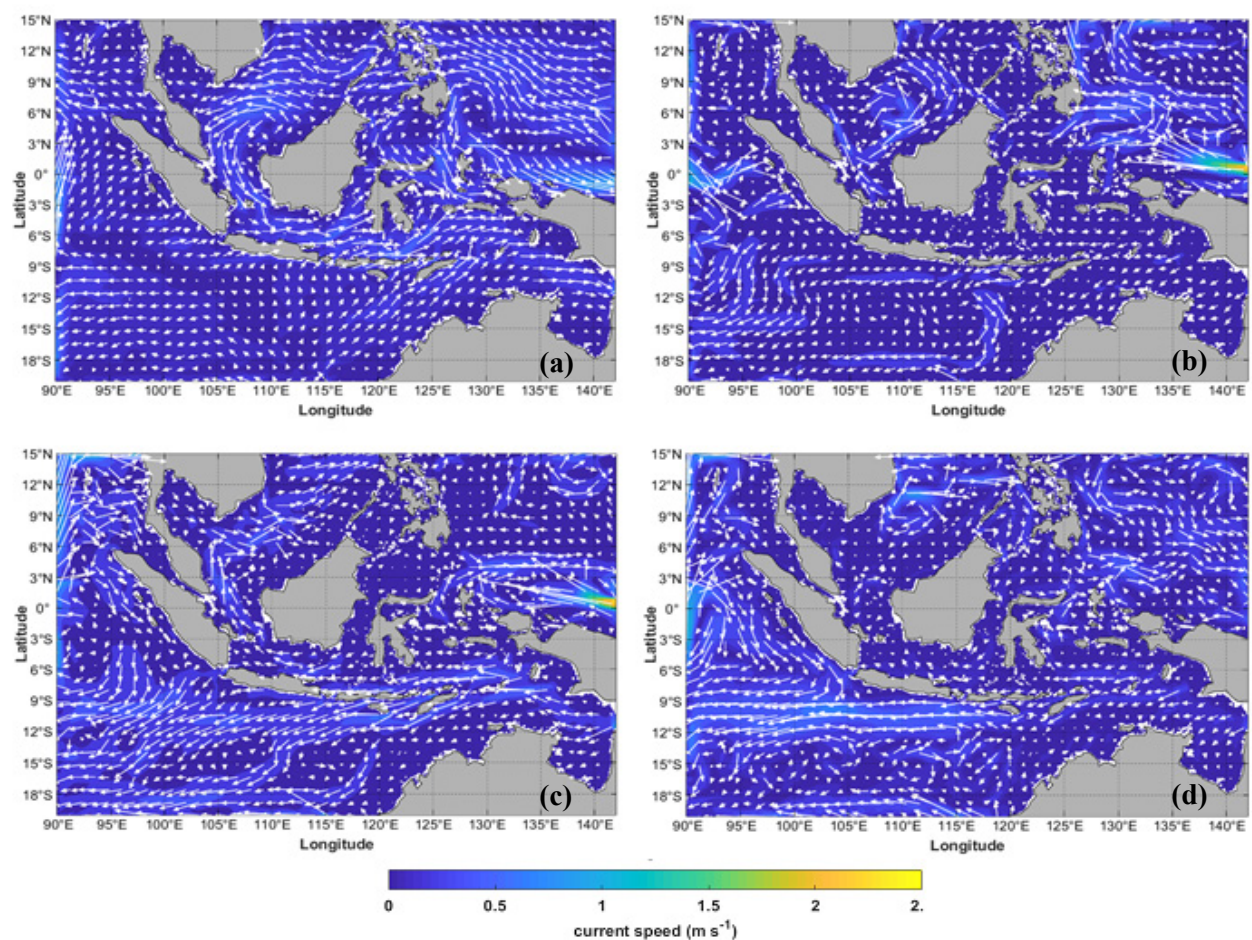

Figure 1. The average surface current velocity in the months: (a) January, (b) April, (c) July, and (d) October 2013.

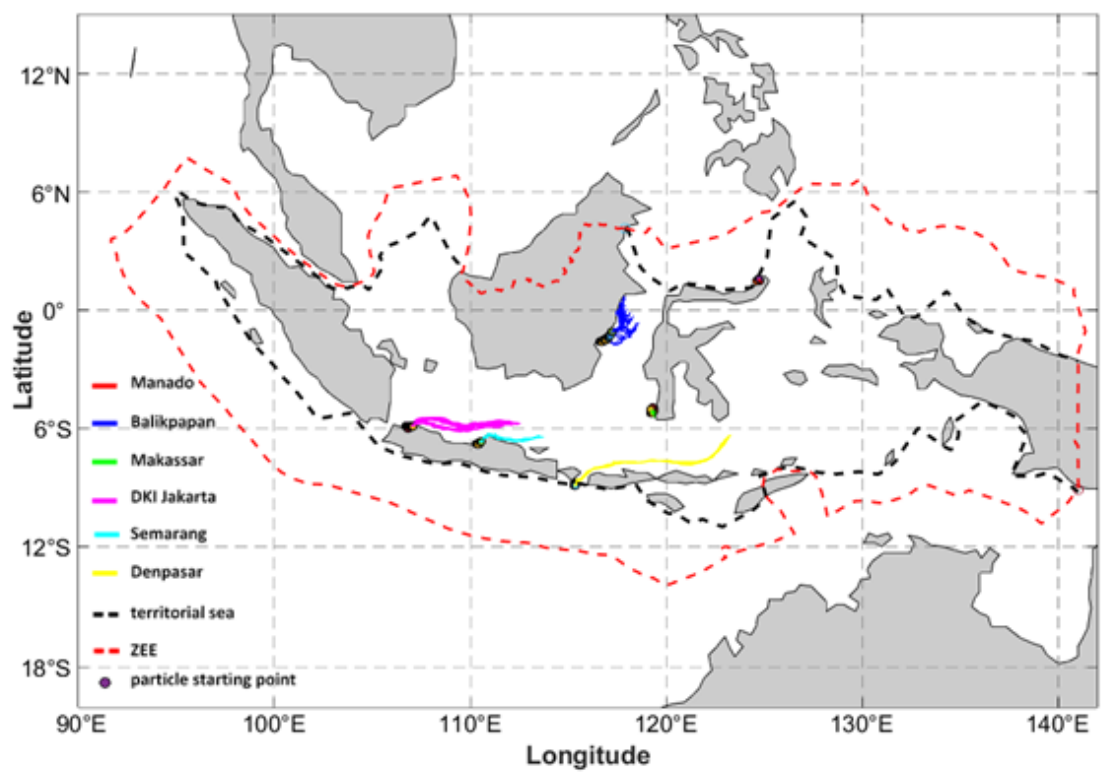

Figure 2. The average surface current velocity in the months: (a) January, (b) April, (c) July, and (d) October 2013. 


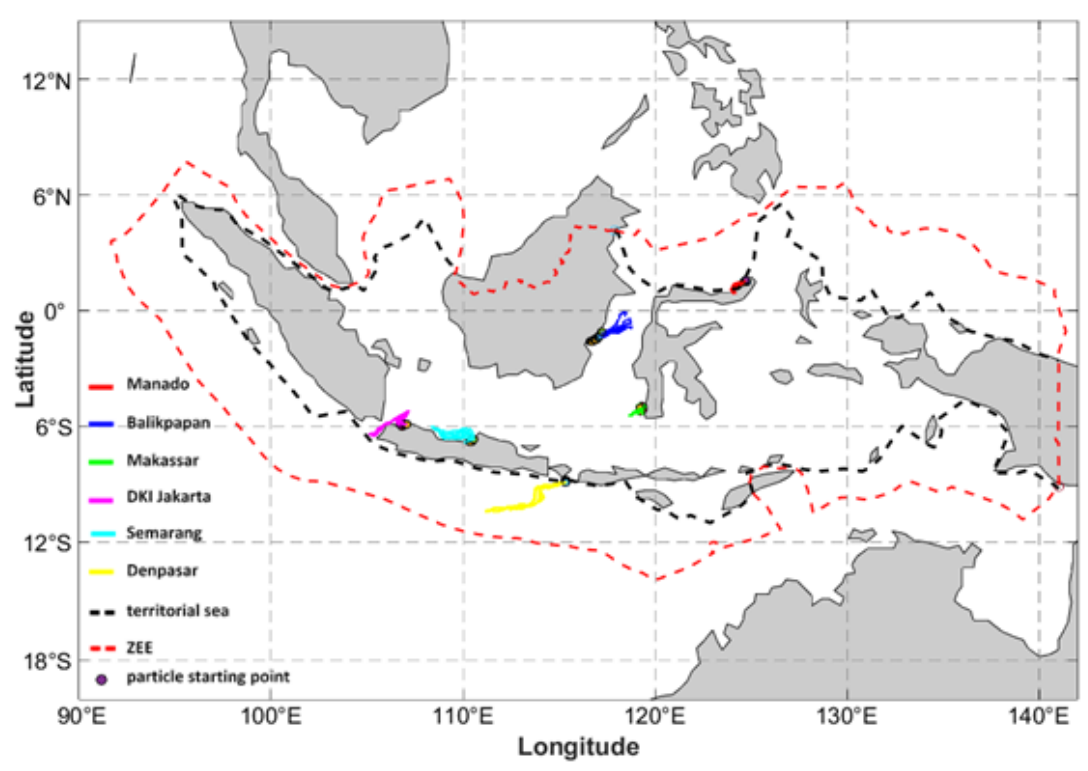

Figure 3. A plot of the simulation results of the trajectory model from six cities during April 2013.

to the northeast (Java Sea) and then reversed towards the Southwest towards the Sunda Strait. In the Sunda Strait, the particles were blocked by currents from the Indian Ocean; as a result, the particles returned to the north into Indonesian waters. The results of the April trajectory simulation for Semarang waters show that all particles from Semarang are carried westward to Indramayu and Cirebon. As a result, Cirebon waters received $77 \%$ of plastic waste shipments, while the remaining $23 \%$ was distributed to Indramayu (Figure $3)$.

Current conditions around Denpasar waters resulted in all particles released in April, carried by currents to the Southwest to the Indian Ocean. These particles leave the Indonesian territorial sea and enter the Indonesian EEZ (Figure 3). The territorial sea is a sea lane with a width of 12 (twelve) miles measured from the baseline of the Indonesian Archipelago (UNCLOS, 1982; Law No. 6 of 1996). The Exclusive Economic Zone (EEZ) of Indonesia, namely: a zone extending as far as 200 miles from the coastline of a country and within that zone a coastal country has rights to natural resources (UNCLOS, 1982).

The simulation results for July show that currents carry particles released in Manado waters to the northeast to the north of North Maluku. As a result,

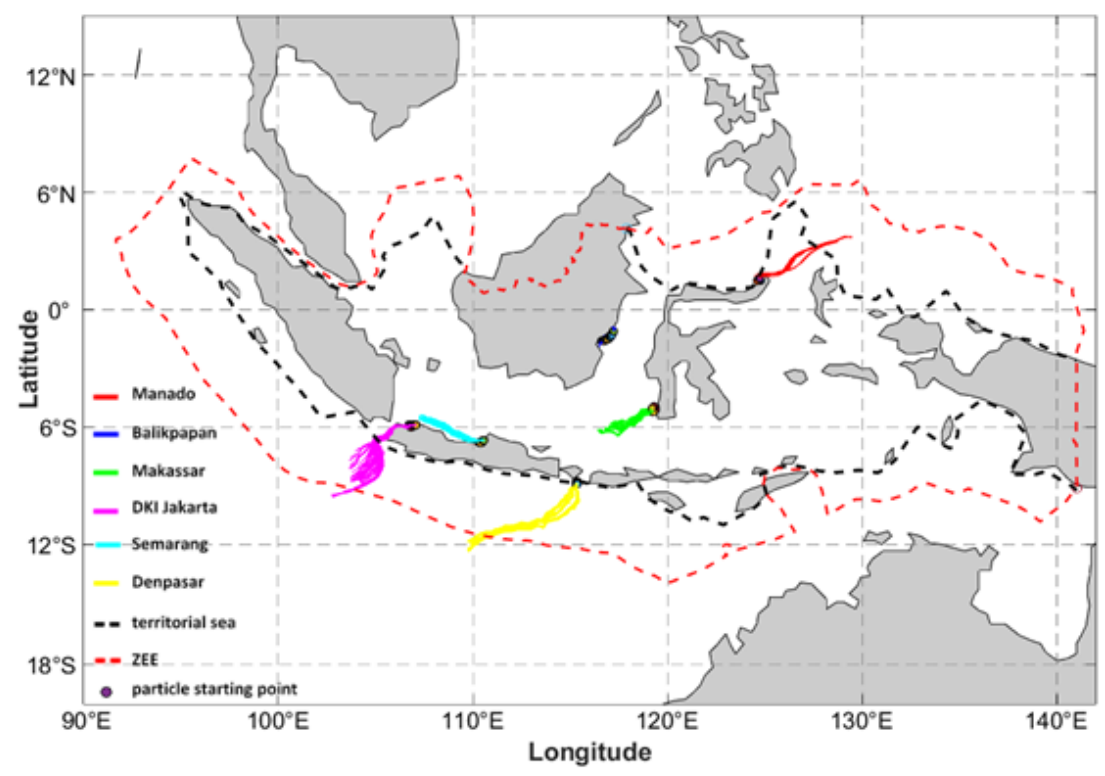

Figure 4. The plot of the simulation results of the trajectory model from six cities during July 2013. 
some particles are taken out of Indonesia's territory and into the Indonesian EEZ. However, unlike the particles released in the waters of Balikpapan, these particles remain around Balikpapan. This condition occurs because the current around Balikpapan moves to the west. On the other hand, particles released in Makassar waters are out of the seas around Makassar, carried by currents to the west to the Java Sea (Figure 4).

Not much different from the particles released in Makassar, the particles released in Semarang are also carried by the current to the west (north of DKI Jakarta). Likewise, with the particles released in DKI Jakarta, all particles are carried by currents to the west and then to the south (Indian Ocean) through the Sunda Strait. This condition also occurs with all particles released in Denpasar, distributed entirely to the south (Indian Ocean). Thus, most of the DKI Jakarta and Denpasar particles leave the Indonesian territorial sea and enter the EEZ area; even some of these particles are carried out of the Indonesian EEZ area (Figure 4).

Current conditions around Manado waters make the particles in Manado waters drift east in October and float to North Maluku waters. However, a different phenomenon occurs in the released particles in the waters of Balikpapan. In October, $67 \%$ of plastic waste washed up again in Balikpapan, $19 \%$ was carried to the northeast (west of Samarinda), while 15\% was taken to the northeast (Makassar Strait) and then turned southeast. In Makassar, the particles released in October are still carried westward towards the Java Sea at a very weak speed. (Figure 5).
In Semarang, particles released in October were carried by currents to the northwest (Java Sea). Similar to particles from Semarang, particles from DKI Jakarta, carried by currents to the west and then to the south (Indian Ocean) through the Sunda Strait. As explained in previous studies, the movement of currents in the Sunda Strait in October also moved towards the Indian Ocean (Purmono et al, 2018). These particles come out of the Indonesian territorial sea, even out of the Indonesian EEZ. Meanwhile, all particles released in Denpasar waters are carried westward, in and out of the Indonesian territorial sea through the coast of Banyuwangi (south of East Java) (Figure 5).

The topic of currents and marine macro debris (not only plastic waste) originating from DKI Jakarta has been discussed in previous studies (Jasmin et al., 2019; Jasmin et al., 2020). In his research, the movement of macro debris is divided into the movement of marine macro debris before and after reclamation in Jakarta Bay. The results show that the formation of the reclamation island affects the movement pattern of macro debris particles, so that Jakarta Bay becomes an accumulation of marine macro debris from the land around the waters of Jakarta Bay.

The results of the hydrodynamic simulation show that the formation of the reclamation island does not change significantly in the offshore area, but a simple change in the surface current pattern of the reclamation area causes a decrease in the flow velocity of \pm 0.002 to $0.02 \mathrm{~m} / \mathrm{s}$ at some points. The simulation of the trajectory of macro waste particles shows that after reclamation, macro waste tends to accumulate in the eastern part of Jakarta Bay in January, and in the western and eastern

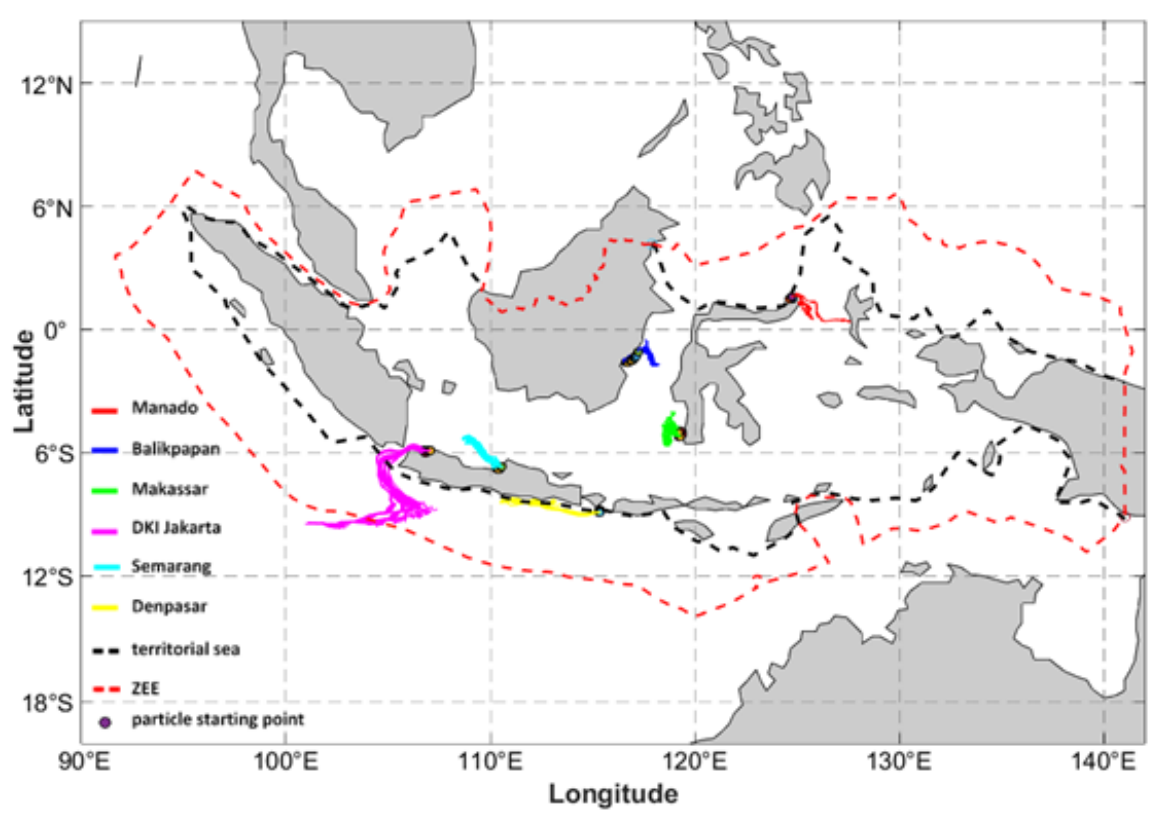

Figure 5. A plot of the simulation results of the trajectory model from six cities during October 2013. 
regions during July.

The results of the trajectory model from four months show that the Java Sea has the potential as a place to collect plastic marine debris. The waste is carried away by the monsoon current which moves east in January, but changes direction to the west in July. This causes garbage to be trapped in the Java Sea (for example: garbage from Makassar, Semarang, DKI Jakarta which moves east in January and west in July). This result is also supported by previous research which explains that microplastics in the Java Sea are thought to have come from the South China Sea and the Pacific Ocean (Handyman et al., 2019).

Other results show that marine debris floating on the surface, originating from Indonesian rivers, tends to wash up on Indonesian beaches. The stranded waste is not only from the nearest source but also contributions from other places that are far from the source. The community observed that from January to April a lot of garbage washed up on Selayar Island (South Sulawesi). This condition also occurs on Wakatobi Island (Southeast Sulawesi), a lot of waste accumulates in December and March (Phelan et al. 2020; Dobler et al, 2021).

\section{CONCLUSION}

Plastic marine debris from 6 sources (Manado, Balikpapan, Makassar, Semarang, DKI Jakarta, and Denpasar) partly remains around the area; some leave the waste source area. In addition, it was also found that some plastic waste was carried by currents out of the territorial sea, into the Indonesian EEZ, and even out of the Indonesian EEZ (about 28-31 days). Therefore, the dynamics of ocean currents in Indonesian waters have a significant role in the movement of marine debris with sources of plastic waste from Indonesia.

These results are expected to provide input for the Indonesian people to be more disciplined in disposing of waste in its place because garbage that enters the sea can be carried by currents and move to areas far from the source of the trash. In addition, the results of this study can also be input for the Indonesian government to take policies in waste management in Indonesia.

\section{ACKOWLEDGEMENTS}

We extend our thanks to the Institute Technology of Bandung, University of Hang Tuah, and Domestic Postgraduate Education Scholarships-Ministry of Research and Technology- Higher Education (BPP DN-RISTEKDIKTI) financial support in facilitating this research.

\section{REFFERENCE}

Anwar, I.P., Putri, M.R., \& Setiawan, A. (2017). Variasi transpor volume dan variabilitas arus laut di Selat Karimata dan Gaspar tahun 2010-2014 berdasarkan model numerik. Jurnal IImu dan Teknologi Kelautan Tropis, 9(2), 771-782. http:// dx.doi.org/ 10.29244/jitkt.v9i2.19309.

Anwar, I.P., Putri, M.R., \& Setiawan, A. (2018). Ocean numerical model experiment on estimating the variation of volume and heat transport in Karimata Strait. IOP Conference Series Earth and Environmental Science, 162(1):012001. https:// doi.org/10.1088/1755-1315/162/1/012001.

Backhaus, J.O. (1983). A semi-implicit scheme for the shallow water equations for application to shelf sea modelling. Continental Shelf Research, 2(4), 243-254.

Backhaus, J.O. (1985). A three-dimensional model for the simulation of shelf sea dynamics, Deutsche Hydrographische Zeitschrift.

Bowman, K.P., Lin, J.C., Stohl, A., Draxler, R., Konopka P., Andrews A., \& Brunner, D. (2013). Input Data Requirements for Lagrangian Trajectory Models. Bulletin of the American Meteorological Society, 94(7), 1051-1058. DOI:10.1175/ BAMS-D-12-00076.1

Coe, J.M., \& Rogers, D.B. (1997). Marine debris: sources, impacts, and solutions, Springer-Verlag New York, Inc.

Dobler, D., Martinez, E., Rahmania, R., Gautama, B. G., Farhan, A. R., \& Maes, C. (2021). Floating marine debris along Indonesia coasts: An atlas of strandings based on Lagrangian modelling, Institute of Research for Development: Project Monitoring and modelling the circulation of marine debris in Indonesia.

Egbert, G.D., \& Erofeeva, S.Y. (2002). Efficient inverse modeling of barotropic ocean tides. Journal of Atmospheric and Oceanic Technology, 19(2), 183-204.

Galgani, F., Fleet, D.M, van Franeker, J. A, Katsanevakis, S., Maes, T., Mouat, J., Oosterbaab, L., Poitou. I., Hanke G., Thompson, R., Amato, E., Birkun, A., \& Janssen, C. (2010): Marine strategy framework directive task group 10 report marine litter directive, European Union, IFREMER dan ICES, https://doi.org/10.2788/86941. 
Gordon, A.L., Giulivi, C.F., \& Ilahude, A.G. (2003). Deep topographic barriers within the Indonesian seas. Deep Sea Research Part II: Topical Studies in Oceanography, 50(12-13), 2205-2228. https:// doi.org/10.1016/S0967-0645(03)00053-5.

Gordon, A.L., Sprintall, J., van Aken, H.M., Susanto, R.D., Wijffels, S.E., Molcard, R., Ffield, A., Pranowo, W.A., \& Wirasantosa, S. (2010). The Indonesian throughflow during 2004-2006 as observed by the INSTANT program. Dynamics of Atmospheres and Oceans, 50(2), 115-128, https://doi.org/10.1016/j.dynatmoce.2009.12.002.

Handyman, D.I.W., Purba, N.P., Pranowo, W.S., Harahap, S.A., Dante, I.F., \& Yuliadi, L.P.S. (2019). Microplastics patch based on hydrodynamic modeling in the north Indramayu, Java Sea. Polish Journal of Environmental Studies, 28(1), 135-142. https://doi.org/10.15244/pjoes/81704.

Huang, B., Thorne, P.W., Banzon, V.F., Boyer, T., Chepurin, G., Lawrimore, J.H., Menne, M. J., Smith, T. M., Vose, R.S., \& Zhang, H (2017). Extended Reconstructed Sea Surface Temperature, Version 5 (ERSSTv5): Upgrade, Validations, and Intercomparisons. J. Climate, 30(20), 8179-8205 https://doi.org/10.1175/JCLI-D-16-0836.1

Jambeck, J.R., Geyer, R., Wilcox, C., Siegler, T.R., Perryman, M., Andrady, A., Narayan, R., \& Law, K.L. (2015). Plastic waste inputs from land into the ocean. Science, 347(6223), 768-771.

Jarvis, A., Reuter, H.I., Nelson, A., \& Guevara, E. (2008). Hole-filled seamless SRTM data V4. International Centre for Tropical Agriculture (CIAT). http://srtm. csi.cgiar.org

Jasmin, H.H., Purba, N.P., Harahap, S.A., Pranowo, W.S., Syamsudin, M.L., \& Faizal, I. (2019). The model of macro debris transport before reclamation and in existing condition in Jakarta Bay. Jurnal IImu dan Teknologi Kelautan Tropis. 11(1), 131-140. http://dx.doi.org/10.29244/jitkt. v11i1.24777.

Jasmin, H.H., Purba, N.P., Pranowo, W.S., Pribadi, T.D.K., Syamsudin, M.L., \& Ihsan, Y.N. (2020). Marine macro debris transport based on hydrodynamic model before and after reclamation in Jakarta Bay, Indonesia. Malaysia Journal of Applied Sciences, 5(2), 100-111. http://dx.doi. org/10.37231/myjas.2020.5.2.241.

Kementrian Koordinator Bidang Kemaritiman, World Bank Group, and Embasy of Denmark. (2017, in Indonesian). A quick assessment of Indonesia's marine debris hotspots: Balikpapan city report

Kementrian Koordinator Bidang Kemaritiman, World Bank Group, \& Embasy of Denmark. (2017, in Indonesian). A quick assessment of Indonesia's marine debris hotspots: Batam city report.

Kementrian Koordinator Bidang Kemaritiman, World Bank Group, and Embasy of Denmark. (2017, in Indonesian). A quick assessment of Indonesia's marine debris hotspots: Denpasar city report.

Kementrian Koordinator Bidang Kemaritiman, World Bank Group, \& Embasy of Denmark. (2017, in Indonesian). Kajian cepat hotspot sampah laut Indonesia: Laporan kota Jakarta.

Kementrian Koordinator Bidang Kemaritiman, World Bank Group, \& Embasy of Denmark. (2017, in Indonesian). A quick assessment of Indonesia's marine debris hotspots: Makassar city report.

Kementrian Koordinator Bidang Kemaritiman, World Bank Group, \& Embasy of Denmark. (2017, in Indonesian). A quick assessment of Indonesia's marine debris hotspots: Manado city report.

Kementrian Koordinator Bidang Kemaritiman, World Bank Group, \& Embasy of Denmark. (2017, in Indonesian). A quick assessment of Indonesia's marine debris hotspots: Semarang city report.

Krelling, A.P., Souza, M.M., Williams, A.T., \& Turra, A. (2017). Transboundary movement of marine litter in an estuarine gradient: Evaluating sources and sinks using hydrodynamic modelling and ground truthing estimates. Marine Pollution Bulletin, 119(1). DOI:10.1016/j.marpolbul.2017.03.034.

Lippiat, S., Opfer, S., \& Arthur, C. (2013). Marine debris monitoring and assessment: Recommendations for monitoring debris trends in the marine environment, NOAA Marine Debris Division.

Locarnini, R.A., Mishonov, A.V., Antonov, J.I., Boyer, T. P., Garcia, H. E., Baranova, O. K., Zweng, M. M., Paver, C. R., Reagan, J. R., Johnson, D. R., Hamilton, M., \& Seidov, D. (2013). World Ocean Atlas 2013, Volume 1: Temperature. S. Levitus, Ed., A. Mishonov Technical Ed.; NOAA Atlas NESDIS 73, 40 pp.

Law of the Republic of Indonesia number 6 year 1996 concerning Indonesian Waters.

Mayer, B. (1995). A three-dimensional numerical suspended particulate matter transport model with application to the German Bight. Disertasi Program Doktor, Universität Hamburg. 
Mayer, B., Damm, P.E., Pohlmann, T., \& Rizal, S. (2010). What is driving the ITF? An illumination of the Indonesian throughflow with a numerical nested model system. Dynamics of Atmospheres and Oceans, 50(2), 301-312, https://doi.org/10.1016/j. dynatmoce.2010.03.002.

Mustikasari, E., Dewi, L.C., Heriati, A., \& Pranowo, W.S. (2014). Pemodelan pola arus barotropik musiman 3 dimensi (3D) untuk mensimulasikan fenomena upwelling di perairan Indonesia. Jurnal Segara, 11(1), 25-35.

NOAA. (2015). Turning the tide on trash. A learning guide on marine debris.

Purmono, P., Monang, S., Alam, T.M., \& Parnowo, W.S. (2018). Rezim horisontal dan vertikal arus monsun di Selat Sunda. Jurnal Hidropolar, 4(1), 25-30. https://doi.org/10.37875/hidropilar.v4i1.93

Putri, M.R. (2005). Study of ocean climate variability (1959-2002) in the Eastern Indian Ocean, Java Sea, and Sunda Strait using the hamburg shelf ocean model, Disertasi Program Doktor, Universitat Hamburg.

Putri, M.R., Setiawan, A., Sari, T., Mayer, B., \& Pohlmann, T. (2017). Trajectory model for identification of oil spill around the coast of Pari Island, Seribu Islands, North Jakarta. Jurnal IImu dan Teknologi Kelautan Tropis, 9(2), 657-664. https://doi.org/10.29244/jitkt.v9i2.19299.

Sprintall, J., \& Revelard, A. (2014). The Indonesian throughflow response to Indo-Pacific climate variability. Journal of Geophysical Research: Oceans, 119(2),1161-1174. DOI:10.1002/2013JC009533

Thompson, R. C., Moore, C. J., Saal, F. S., and Swan, S. H. (2009). Plastics, the environment, and human health: current consensus and future trends. Philosophical Transactions of the Royal Society B, 364(1526), 2153-66, https://doi.org/10.1098/ rstb.2009.0053.

United Nations Convention on the Law of the Sea. (1982). A Commentary - Volume VI.

Wyrtki, K. (1987). Indonesian through flow and the associated pressure gradient. Journal of Geophysical Research, 92(C12), 12941, https:// doi.org/10.1029/ JC092iC12p12941.

Zweng, M.M., Reagan, J.R., Antonov, J.I., Locarnini, R. A., Mishonov, A.V., Boyer, T.P., Garcia, H.E., Baranova, O.K., Johnson, D.R., Seidov, D., \&
Biddle, M.M. (2013). World Ocean Atlas 2013, Volume 2: Salinity. S. Levitus, Ed., A. Mishonov Technical Ed.; NOAA Atlas NESDIS 74, 39 pp. 
The Movement Of Plastic Marine Debris ...... using A Trajectory Model (Kusniarti, E.A., et al.) 